Volume 15 (3) (2019) : 333-352
Jurnal Borne0 Administrator
p-issn : 1858-0300; e-issn : 2407-6767
http://samarinda.lan.go.id/jba
$\mathrm{DOl}: 10.24258 / j b a . v 15 i 3.499$

\title{
KONTEKS LEMBAGA DALAM IMPLEMENTASI KEBIJAKAN PENGURANGAN KEMATIAN BAYI DI KABUPATEN KUPANG
}

\section{INSTITUTIONAL CONTEXT IN IMPLEMENTING POLICY FOR REDUCE INFRANT MORTALITY IN KUPANG REGENCY}

\author{
Mariayani Rene a , Kismartini a,b, dan Hartuti Purnaweni a,c \\ a Magister Administrasi Publik, FISIP, Universitas Diponegoro \\ b Program Studi Administrasi Publik, Sekolah Pascasarjana, Universitas \\ Diponegoro \\ c Program Studi IImu Lingkungan, Sekolah Pascasarjana, Universitas Diponegoro \\ JI. Prof. Soedarto SH, Tembalang, Kec. Tembalang, Kota Semarang \\ Email: mariayanirene@gmail.com
}

Naskah diterima: 29 April 2019; revisi terakhir: 14 November 2019; disetujui: 21 November 2019 How to Cite: Rene, Mariayani., Kismartini, dan Purnaweni, Hartuti. (2019). Konteks Lembaga dalam Implementasi Kebijakan Pengurangan Kematian Bayi di Kabupaten Kupang. Jurnal Borneo Administrator, 15 (3), 333-352. https://doi.org/10.24258/jba.v15i3.499

\begin{abstract}
Policy implementation is a complex process because there are many conditions affecting in the process. One of them is the institutional context, as a corridor which policy must travel. Maternal and child health is an important policy in Indonesia, this is related to the high rate of infant mortality in Indonesia. One of the highst infrant Mortality rate in Indonesia is Kupang Regency, therefore the regencyal government made a Regional Regulation (Perda) No 3 of 2016 for reduce mother and infrant mortality. The purpose of this study is to analyze the institutional context in implementing of Perda No. 3 Tahun 2016 for reduce infant mortality in Kupang Regency by Najam (1995). This study use qualitative descriptive. The results show the problem of institutional context in policy implementation for reduce infrant moratlity in Kupang Regency are: the subdistrict head and headman are less active in carrying out their duties, lack of society participation. Another problem in institutional context in this policy is conditions of environmental in Kupang Regency, such as geographical conditions, Poor Education, poor sanitation, and also the traditional festival Se'i by the Local Community.
\end{abstract}

Keywords: Policy Implementation, Institutional Context, Infant Mortality 


\begin{abstract}
Abstrak
Implementasi kebijakan merupakan suatu proses yang kompleks, karena ada berbagai kondisi yang turut berpengaruh dalam prosesnya, salah satunya adalah konteks lembaga, sebagai prosedur operasi yang harus dilalui sebuah kebijakan dalam proses implementasinya. Kebijakan kesehatan ibu dan anak merupakan sebuah kebijakan yang penting di Indonesia, hal ini berkenaan dengan tingginya Angka KematianBayi (AKB) Indonesia. Salah satu daerah di Indonesia yang memiliki AKB yang tinggi ialah Kabupaten Kupang, oleh karena itu pemerintah Kabupaten Kupang membuat sebuah kebijakan berupa Perda No. 3 Tahun 2016 tentang KIBBLA untuk mengurangi kematian ibu dan khususnya kematian bayi. Tujuan penelitian ini ialah untuk menganalisis konteks dalam implementasi kebijakan Perda No. 3 tahun 2016, dengan mengacu pada teori model implementasi Najam (1995). Metode penelitian adalah deskriptif kualitatif. Hasil penelitian menunjukkan permasalahan yang muncul pada konteks lembaga dalam implementasi kebijaka pengurangan kematian bayi ialah kurangnya peran aktif dari Lurah dan Kepala desa dalam melaksanakan apa yang menjadi tanggung jawab mereka dalam implementasi kebijakan, serta kurangnya partisipasi aktif dari masyarakat. Realitas lingkungan Kabupaten Kupang, berupa kondisi geografis, tingkat pendidikan, buruknya sanitasi, dan juga tradisi Se'i oleh masyarakat setempat juga menjadi hambatan dalam implementasi kebijakan.
\end{abstract}

Kata Kunci: Implementasi Kebijakan, Konteks Lembaga, Angka Kematian Bayi

\title{
A. PENDAHULUAN
}

Implementasi menjadi suatu tahapan yang penting dalam proses kebijakan. Implementasi pada prinsipnya adalah cara agar sebuah kebijakan dapat mencapai tujuan (Nugroho, 2014:728). Implementasi kebijakan juga merupakan sebuah fenomena yang kompleks (Winarno,2012:148), implementasi menjadi kompleks karena dalam implementasi kebijakan melibatkan berbagai aktor dan sumber daya serta adanya berbagai kondisi dalam pelaksanaannya (Grindle, 1980:3). Hasil kajian yang dilakukan oleh Najam, (1995); Bayrakal, (2006); Martin, (2014); dan Mthethwa, (2017) menunjukkan ada berbagai faktor penting yang berpengaruh dalam proses implementasi sebuah kebijakan publik. Najam (1995:12) menguraikan lima faktor penting yang berpengaruh dalam proses implementasi kebijakan publik. Kelima faktor ini, dikenal dengan istilah 5C Protocol, yaitu: 1) content atau isi dari kebijakan, 2) context, yaitu konteks dari lembaga pelaksana kebijakan, 3) commitment, yaitu komitmen dari aktor pelaksana, 4) capacity, atau kapasitas dari aktor pelaksana kebijakan, dan 5) clients and coalitions, yaitu pihak-pihak yang dipengaruhi penerapan sebuah kebijakan.

Berdasarkan kelima faktor yang berperan penting dalam proses implementasi yang menjadi menarik untuk dikaji ialah faktor konteks lembaga (Institutional context). Faktor konteks (context) diuraikan oleh Najam (1995) sebagai salah satu faktor penting dalam implementasi kebijakan, hal ini dikarenakan konteks dari lembaga yang mencangkup aktor kunci, hubungan antara lembaga pelaksana, dan karateristik dari lembaga akan berdampak pada lembaga tersebut dalam mentransferkan suatu kebijakan menjadi tindakan. Faktor konteks (context) juga memperhatikan realitas lingkungan setempat yang juga turut 
berdampak pada proses implementasi kebijakan. (Nurani, Mardiyono, Supriyono, \& Wijaya. 2018:27; Dongol 2011:24; Bayrakal 2006:133-134).

Adanya berbagai faktor dalam proses implementasi kebijakan, menimbulkan gap antara apa yang menjadi tujuan dari kebijakan dengan fakta yang terjadi. Hal ini pula yang mungkin terjadi dalam proses implementasi salah satu kebijakan yang sangat penting saat ini yaitu kebijakan kesehatan ibu dan anak, khususnya berkenaan dengan kebijakan untuk pengurangan Angka Kematian Bayi (AKB).

Kematian bayi adalah salah satu masalah kesehatan masyarakat yang telah menjadi fokus dunia selama beberapa dekade, dan saat ini lebih menjadi perhatian karena adanya faktor-faktor risiko yang muncul dari kesenjangan ekonomi antara si kaya dan si miskin yang semakin meluas (Swartz, 2013: 407). Isu kematian bayi juga menjadi agenda pembangunan global yang ditetapkan oleh Perserikatan Bangsa-Bangsa yang dikenal dengan Millenium Development Goals (MDGs) 1990-2015 yaitu pada Goal ke empat untuk mengurangi kematian anak bayi menjadi lebih dari setengahnya, turun dari 90 menjadi 43 kematian per 1.000 kelahiran hidup (United Nations, 2019). MDGs kemudian dilanjutkan dengan Sustainable Development Goals (SDGs) 2015-2030, dimana target ketiga dari SDGs ialah memastikan kehidupan yang sehat dan mempromosikan kesejahteraan untuk semua manusia disegala usia. SDGs ini memiliki target baru yang diusulkan yang bertujuan untuk mengurangi kematian neonatal hingga paling rendah 12 kematian per 1.000 kelahiran hidup dan kematian balita hingga paling rendah 25 kematian per 1.000 kelahiran hidup (UNICEF, 2018).

Indonesia merupakan salah satu dari negara berkembang dengan AKB yang tinggi, bahkan yang tertinggi di kalangan negara-negara ASEAN, padahal angka kematian bayi menjadi salah satu indikator utama derajat kesehatan suatu negara, sehingga mempengaruhi pembangunan kesehatan negara tersebut (Bappenas, 2016). Secara definisi, AKB merupakan jumlah bayi yang meninggal pada fase antara kelahiran hingga bayi belum mencapai umur satu tahun Per 1000 Kelahiran Hidup.

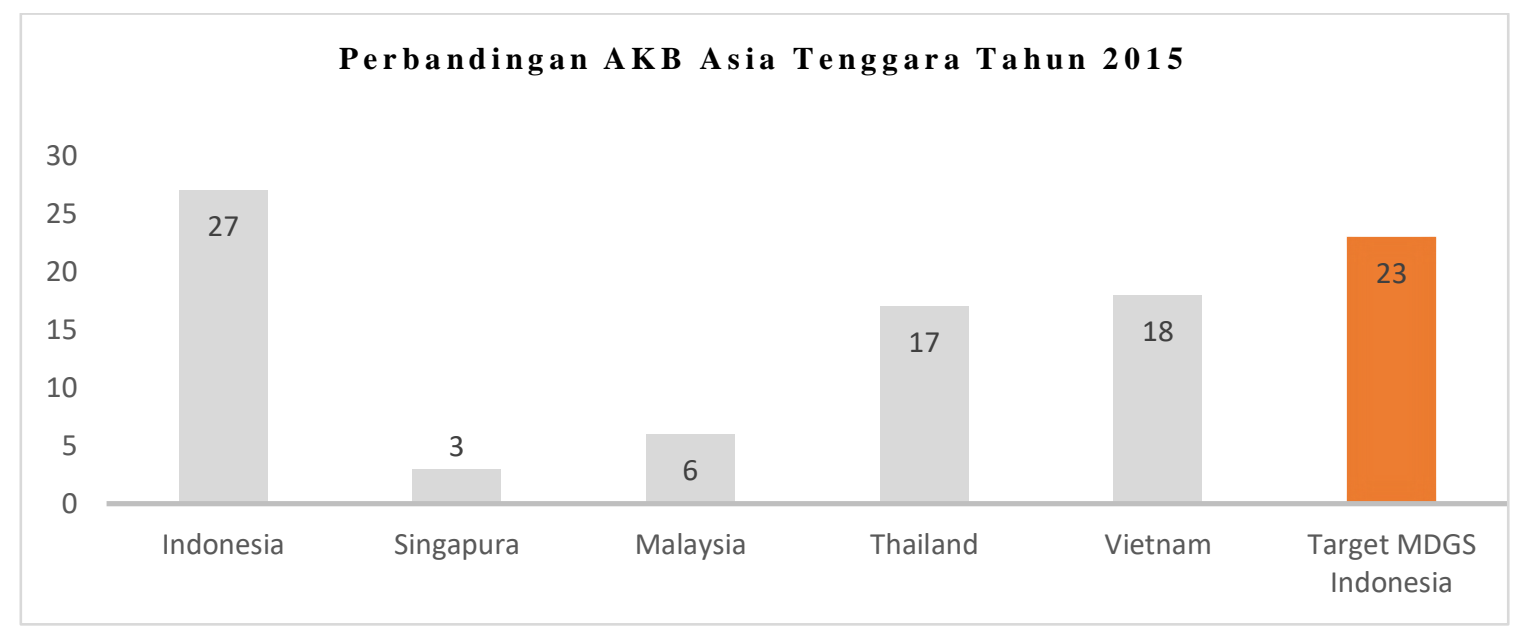

Gambar1.

AKB di Beberapa Negara ASEAN Tahun 2015 dan Target MDGS Indonesia Tahun 2015 (Sumber: ASEAN Community Relation Division, 2017)

Gambar 1 menunjukkan bahwa AKB Indonesia pada tahun 2015 masih mencapai 27 Per $1000 \mathrm{KH}$, sehingga belum mencapai target akhir MDGs Indonesia yaitu 23 Per $1000 \mathrm{KH}$. Dibandingkan dengan Negara-negara tetangga ASEAN, terlihat bahwa posisi AKB 
Indonesia masih jauh dari dari AKB Singapura yang ada pada tingkat AKB 3 Per 1000 dan Malaysia pada AKB 6 Per 1000 KH.

Menurut Data BPS Indonesia (2018) salah satu provinsi yang memiliki angka kematian bayi yang tinggi ialah Nusa Tenggara Timur (NTT). Pada tahun 2012 Angka Kematian Bayi di NTT masih pada tingkat 57 Per 1000 KH, dibandingkan dengan Angka Kematian Bayi Indonesia yaitu 34 Per 1000 KH. Sementara untuk wilayah NTT, Kabupaten Kupang merupakan salah satu daerah dengan Angka Kematian Bayi yang tinggi (Dinas Kesehatan Kabupaten Kupang, 2018). Kasus kematian bayi yang dilihat dari setiap indikator AKB yang terjadi di Kabupaten Kupang selama beberapa kurun waktu terlihat sebagaimana ditunjukkan pada Tabel 1.

Tabel 1.

Kasus Kematian Bayi di Kabupaten Kupang Tahun 2012-2017

\begin{tabular}{lrrrrrrr}
\hline \multicolumn{1}{c}{ Indikator AKB } & \multicolumn{7}{c}{ Tahun } \\
& 2012 & 2013 & 2014 & 2015 & 2016 & \multicolumn{1}{c}{2017} \\
\hline Bayi Lahir Mati & 87 & 56 & 88 & 98 & 92 & 126 \\
Kematian Neonatal & 54 & 47 & 43 & 63 & 69 & 59 \\
Kematian Bayi & $*$ & 24 & 29 & 37 & 20 & 27 \\
\hline
\end{tabular}

Sumber: (Dinas Kesehatan Kabupaten Kupang, 2018)

Tingginya AKB di Indonesia, khususnya di Kabupaten Kupang membuat isu kesehatan bayi di Indonesia harus menjadi perhatian serius di ranah administrasi publik. Administrasi publik sebagai the work of government yang memiliki peran atau pengaruh yang sangat vital dalam suatu negara. Apa yang dikerjakan di dalam ranah administrasi publik ialah hal-hal yang dikerjakan oleh Pemerintah bersama stakeholder lainnya menyangkut penyediaan layanan barang dan jasa yang berkaitan dengan kepentingan atau kebutuhan publik (Yeremias.T, 2014 :15-17), khusunya pelayanan publik yang sifatnya sangat mendasar seperti pendidikan dan kesehatan. Merujuk pada hal ini, maka pemerintah Indonesia baik itu pemerintah pusat maupun pemerintah daerah Kabupaten Kupang sebagai administrator penyelenggaraan negara berkewajiban menyediakan layanan kesehatan, termasuk layanan kesehatan ibu dan anak guna menurunkan Angka Kematian Bayi.

Selain menyediakan layanan kesehatan, dalam upaya pengurangan AKB, pemerintah juga dapat membuat kebijakan yang dapat dipakai untuk mempengaruhi perilaku masyarakat, sehingga masyarakat juga akan turut terlibat dalam upaya pengurangan AKB. Peterson (2003:1030) menjelaskan arti dari kebijakan publik sebagai aksi pemerintah dalam menghadapi masalah, dengan mengarahkan perhatian terhadap siapa mendapat apa, kapan dan bagaimana. Berkenaan dengan tingginya kasus kematian bayi di Kabupaten Kupang, Pemerintah Kabupaten Kupang mengeluarkan kebijakan publik untuk menangani masalah ini. Pada tahun 2010 mengikuti kebijakan Revolusi KIA (Kesehatan Ibu dan Anak) NTT, Pemerintah Kabupaten Kupang membuat kebijakan berupa Peraturan Bupati (Perbup) No. 16 tahun 2010 tentang Percepatan Pelayanan Kesehatan Ibu dan Anak di Kabupaten Kupang. Selanjutnya,pada tahun 2016 disusul dengan Peraturan Daerah (Perda) No 3 Tahun 2016 tentang Kesehatan Ibu, Bayi Baru Lahir, Bayi dan Anak Bawah Lima Tahun (KIBBLA). Perda ini juga merupakan pengganti Peraturan Bupati No 16 tahun 2010. Penetapan Perda ini merupakan wujud penyelenggaraan kegiatan administrasi publik oleh Pemerintah Kabupaten Kupang untuk memenuhi kebutuhan masyarakat Kabupaten Kupang berupa kepastian jaminan pelayanan dan perlindungan pelayanan kesehatan pada ibu hamil, ibu melahirkan, bayi baru lahir, bayi dan anak bawah lima tahun (KIBBLA). 
Walaupun telah ada Kebijakan kesehatan ibu dan anak untuk menurunkan AKI (Angka Kematian Ibu) dan AKB di Kabupaten Kupang, namun data pada Tabel 1 menunjukkan bahwa kasus kematian ibu, dan khususnya kasus kematian bayi dari tahun 2012 hingga 2017 tidak mengalami penurunan yang signifikan. Bahkan pada tahun 2017 justru terjadi peningkatan kasus kematian pada indikator AKB yaitu kasus bayi lahir mati di Kabupaten Kupang yang mengalami peningkatan sebesar 26, 98\%, dari 92 Kasus pada 2016 menjadi 126 kasus di tahun 2017. Padahal implementasi dari kebijakan kesehatan ibu dan anak, berupa Peraturan daerah No. 3 Tahun 2016 tentang Kesehatan Ibu, Bayi Baru Lahir, Bayi dan Anak Bawah Lima Tahun (KIBBLA) diharapkan dapat menurunkan kasus kematian ibu dan anak di Kabupaten Kupang melalui pengurangan semua indikator baik itu kematian ibu, bayi lahir mati, kematian neonatal, kematian bayi dan kematian balita.

Berbagai penelitian yang mengkaji implementasi kebijakan kesehatan ibu dan anak, khususnya tentang kematian bayi, diantaranya ialah penelitian dari Akinlo dan Sulola (2019) tentang biaya pelayanan kesehatan dan kematian bayi di Sub-Sahara Afrika, dimana kebijakan implementasi kebijakan untuk pengurangan kematian bayi tidak berhasil mencapai tujuan karena tidak efisiensinya biaya kesahatan dan juga tingginya kasus korupsi yang terjadi. Penelitiannya dilakukan oleh Pandey dan Mohan (2019) tentang implementasi kebijakan National Rural Health Mission (NRHM) dalam menurunkan kematian bayi di India, dimana hasil penelitiannya menunjukkan bahwa kebijakan NRHM berhasil menurunkan angka kematian bayi di India karena adanya penguatan infrastruktur pelayanan kesehatan di desa. Di indonesia (Nurani et al., 2018) melakukan kajian tentang implementasi kebijakan untuk mengurangai kematian ibu dan bayi di Jawa Timur, dimana hasil penelitiannya menunjukkan bahwa implementasi kebijakan pengurangan kematian ibu dan bayi di Jawa Timur berhasil karena adanya inovasi dari pemerintah dan pelibatan berbagai pihak yang berkepentingan. Berdasarkan dua jenis penelitian ini, maka penelitian ini berusaha mengkaji bagaimana faktor konteks pada implementasi kebijakan pengurangan kematian bayi di Kabupaten Kupang,dengan fokus penelitiannya pada lembaga-lembaga yang menjadi pelaksana, aktor kunci, hubungan kepentingan antra lembaga pelaksana dan realitas lingkungan Kabupaten Kupang.

\section{B. METODE PENELITIAN}

Penelitian ini menggunakan pendekatan deskriptif kualitatif, karena penelitian kualitatif menekankan pada upaya pengumpulan data di lapangan berdasarkan pengalaman dan pengamatan pada partisipan (Creswell \& Creswell, 2018:42). Fokus penelitian ini ialah pada konteks lembaga dalam implementasi kebijakan pengurangan kematian bayi di Kabupaten Kupang. Penelitian dilakukan di Kabupaten Kupang tepatnya di Kecamatan Kupang Tengah dan Kecamatan Kupang Timur. Kecamatan Kupang Tengah merupakan daerah yang cenderung mengalami peningkatan kasus kematian bayi dari tahun 2013 hingga 2017, sementara itu Kecamatan Kupang Timur merupakan daerah yang selalu mengalami pengurangan kasus kematian bayi dari tahun 2013 hingga 2017 (BPS Kabupaten kupang, 2018).

Pemilihan informan dalam penelitian ini dilakukan dengan menggunakan teknik purposive yang artinya informan ditentukan dengan pertimbangan dan tujuan tertentu, yang dalam penelitian ini ialah; Kepala Dinas Kesehatan Kabupaten Kupang, Kassie Gizi dan keluarga Dinas Kesehatan Kabupaten Kupang, Camat Kupang Tengah, dan Kepala Puskesmas di Kecamatan Kupang Tengah dan Kecamatan Kupang Timur karena dianggap paling mengaetahui permasalahan kematian bayi di Kabupaten Kupang. Dalam penelitian ini juga menggunakan teknik snowballing guna memperoleh informasi yang lebih lengkap 
dan akurat, adapun informan yang dipilih menggunakan teknik ini ialah; bidan desa, aparat desa, Lurah, dan masyarakat Kabupaten Kupang. pengumpulan data dilakukan dengan menggunakan teknik wawancara, observasi dan studi kepustakan. Untuk keabsahan data, digunakan triangulasi sumber dan juga triangulasi teori. Analisa data dalam penelitian kualitatif dilakukan pada saat pengumpulan data berlangsung dan setelah selesai di lapangan. Teknik analisa data yang digunakan dalam penelitian ini adalah dengan menggunakan teknik analisa data kualitatif mengikuti konsep yang diberikan oleh Miles \& Huberman (1994:10$\underline{12}$ ), yaitu dengan pengumpulan data di lapangan, reduksi data, penyajian data dan penarikan kesimpulan.

\section{KERANGKA TEORI}

\section{Kebijakan Publik}

Kebijakan publik menurut Dye (1976) adalah studi tentang apa yang dilakukan oleh pemerintah, mengapa pemerintah mengambil tindakan tersebut dan apa akibat tindakan tersebut (Parsons, 2014:xi). Sementara itu Edward (1980) menjelaskan kebijakan publik sebagai suatu tindakan pemerintah yang berupa program-program pemerintah untuk pencapaian sasaran atau tujuan (Suwitri 2008: 9). Riant Nugroho menjelaskan arti kebijakan publik sebagai jalan mencapai tujuan bersama yang dicita-citakan (Nugroho 2014:183). Berdasarkan beberapa defenisi kebijakan publik yang dibersikan oleh para ahli dapat ditarik simpulan bahwa kebijakan publik merupakan tindakan pemerintah untuk melakukan atau tidak melakukan sesuatu terhadap suatu isu, atau permasalahan publik, dimana dalam memutuskan tindakannya ini pemerintah memperhatikan usulan dan saran dari berbagai pihak, baik itu dari internal pemerintahan maupun luar pemerintah.

\section{Implementasi Kebijakan Publik}

Implementasi sebagai salah satu tahap penting dalam proses pembuatan kebijakan, merujuk untuk pelaksanaan hukum, di mana berbagai pemangku kepentingan dan organisasi bekerja bersama dengan penggunaan prosedur dan teknik untuk memberlakukan kebijakan untuk mencapai tujuan (Khan \& Khandaker, 2016:540). Implementasi Kebijakan juga dijelaskan sebagai proses, keluaran, dan hasil, dan melibatkan beberapa aktor, organisasi dan teknik untuk kontrol, yang merupakan proses interaksi antara menetapkan tujuan dan tindakan yang diarahkan mencapainya (Paudel 2009:36).

Perkembangan studi implementasi yang terjadi saat ini tentu saja tidak terlepas dari perkembangan ilmu administrasi publik, hal ini dikarenakan studi implementasi itu sendiri yang menjadi bagian dari studi administrasi publik (Purwanto \& Sulistyastuti, 2015:34). Dalam perkembangannya studi implementasi telah bergeser dari generasi pertama hingga saat ini ialah generasi ketiga. Salah satu studi implementasi generasi ketiga Adil Najam yang merumuskan konsep $5 \mathrm{C}$ protocol sebagai model implementasi kebijakan.

\section{Model Implementasi Kebijakan Adil Najam (1995)}

Sejumlah kajian yang telah dilakukan seperti Chaya et al. (2019); Kismartini \& Bungin, (2019); Nurani et al. (2018); Mthethwa (2017); Martin (2014); Dongol (2011); dan Bayrakal (2006) dengan mengacu pada pendekatan implementasi kebijakan Najam. Implementasi kebijakan bukanlah sesuatu yang mudah, hal ini dikarenakan implementasi kebijakan memiliki sifat yang dinamis dalam prosesnya. Hal ini juga yang diungkapkan oleh ahli lainnya seperti Pressman \& Wildavsky (1984) yaitu implementasi sebagai sebuah konsep yang tidak mudah untuk ditetapkan (Najam:27). Untuk itu Adil Najam melakukan studi 
untuk mengidentifikasi sekelompok variabel kunci yang digunakan oleh para sarjana dari berbagai pandangan yang berbeda (top-down dan button-up), dengan isu-isu yang berbeda seperti isu lingkungan dan pendidikan, dan dari sistem politik yang berbeda, seperti federal dan kesatuan dan juga negara yang berbeda level tingkat pembangunan ekonominya. Berdasarkan hasil studinya Adil Najam kemudian merumuskan 5 (lima) variabel penting yang di kenal dengan 5C Protocol yangberdampak kepada implementasi kebijakan publik.

Kelima (5C) protocol Najam ialah sebagai berikut: pertama, konten (content) yaitu apa yang ada dalam isi kebijakan publik yang berpengaruh terhadap proses implementasi kebijakan tersebut. Isi kebijakan ini terdiri atas apa yang ditetapkan oleh kebijakan untuk harus dicapai (tujuan dari kebijakan), pengkajian dari masalah, yaitu apakah isi kebijakan menguraikan sebab dan akibat dari masalah (teori kausal), dan cara muntuk memecahkan masalah yang ada (metode). Kedua, konteks (context) yaitu konteks dari lembaga yang lebih sering dikatakan sebagai koridor atau jalan sebagai struktur prosedur operasi yang harus dilalui oleh sebuah kebijakan dalam proses implementasinya. Ketiga, komitmen (commitment) dari pihak yang dipercayakan untuk melakukan kebijakan, dengan memperhatikan tujuan pada berbagai tingkat, sebab akibat dari masalah, dan cara untuk mengatasi masalah. Keempat, kapasitas (capacity) dari pelaksana kebijakan untuk mengimplementasikan kebijakan. Kelima, klien dan koalisi (Clients and Coalitions) yang kepentingannya didukung ataupun diganggu oleh implementasi dari sebuah kebijakan. Adapun gambaran dari kelima variabel tersebut ialah sebagai berikut:

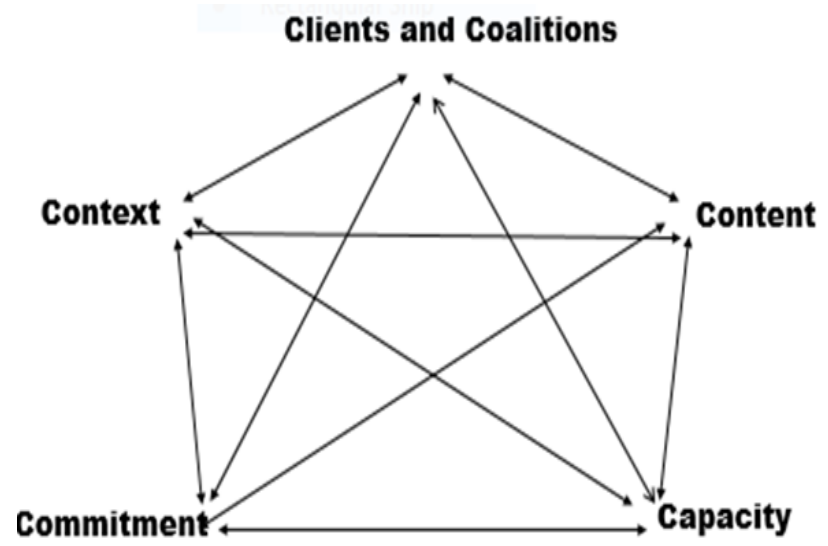

Gambar 2.

Model Implementasi Kebijakan Adil (Sumber: Najam, 1995)

\section{Faktor Konteks (context) dalam Implementasi Kebijakan}

Faktor konteks (context) oleh Najam (1995) dijelaskan sebagai the corridor (often structured as operating procedures) through which policy must travel, and by whose boundaries it is limited, in the process of implementation. Secara sederhana dijelaskan arti penting dari konteks lembaga ialah koridor atau jalan sebagai struktur prosedur operasi yang harus dilalui oleh sebuah kebijakan dalam proses implementasinya (Nurani et al., 2018: 27; Mthethwa, 2017:37). Dalam upaya pemahaman akan faktor konteks dari suatu lembaga dalam implementasi suatu kebijakan, Najam mengatakan ada tiga hal yang terkait konteks lembaga (institutional context) yang perlu untuk dikerjakan, yaitu; 1) mengidentifikasi aktor kunci lembaga yang mempengaruhi atau dipengaruhi oleh proses, 2) melacak hubungan kepentingan dan kekuasaan antara dan di dalam lembaga yang terkait, 3) mengenali karateristik lembaga yang secara struktur dipengaruhi oleh sosial, ekonomi, politik dan 
aturan hukum dimana mereka beroperasi (Kismartini \& Bungin (2019: 105); Nurani et al., (2018:27); Mthethwa (2017:37); Martin (2014:50); dan Dongol (2011:35).

Namun konteks kelembagaan menurut dijelaskan oleh Najam mencakup lebih dari sekadar jaringan hubungan antara lembaga pelaksana. Hal penting lainnya dari variabel ini adalah proses saling adopsi antara lembaga pelaksana dan kebijakan yang sedang dilaksanakan. Karena adanya kemungkinan bahwa satu program yang sama akan melibatkan banyak lembaga yang berbeda baik secara langsung atau tidak langsung, dan juga adanya kemungkinan lembaga-lembaga tertentu akan terlibat langsung ataupun tidak langsung dalam pelaksanaan banyak kebijakan dan program yang berbeda. Hal ini akan membentuk respons lembaga terhadap unsur-unsur tertentu dari kebijakan yang pada akhirnya dapat membentuk kembali kebijakan itu sendiri (Najam, 1995:43).

Perumusan variabel konteks (context) dilakukan Najam dengan memperhatikan sebuah diskusi yang sistematis tentang konteks (context) dari berbagai ahli terdahulu diantaranya; Grindle (1980) yaitu pada skema kedua konteks yang dilihat dari karakteristik lembaga dan regim, yang lebih sering dilabelkan sebagai faktor lingkungan (environmental factors ) oleh beberapa ahli seperti Warwick (1982), dan Najam (1995:41). Berkaitan dengan konteks yang dilihat dari lingkungan dimana suatu kebijakan diimplementasikan, Najam setuju dengan apa yang dikatakan oleh Donald P. Warwick bahwa perbedaan umum antara program yang berjalan dan program yang gagal yaitu yang pertama menghubungkan antara tujuan kebijakan dengan realitas lingkungan, dan yang kedua disebabkan oleh lingkungan yang invariant dan irelevan. Sehingga esensi dari faktor konteks (context) dalam implementasi kebijakan menekankan pada konteks dari lembaga pelaksananya (institutional context) yang dilihat dari; aktor kunci pelaksana kebijakan sebagai pihak yang paling mempengaruhi dan dipengaruhi proses implementasi, hubungan kepentingan dan kekuasaan antara lembaga pelaksana, karateristik dari lembaga pelaksana, dan juga faktor konteks yang dilihat dari realitas lingkungan dimana kebijakan tersebut diimplementasikan (Najam, 1995:45; \& Martin, 2014:50).

\section{HASIL DAN PEMBAHASAN}

Arti penting dari konteks lembaga (institutional context) dalam implementasi kebijakan seperti yang disampaikan oleh Najam (1995: 35) ialah sebagai koridor atau suatu Struktur Prosedur Operasi yang harus dilalui oleh sebuah kebijakan dalam proses implementasinya. Merujuk pada konsep ini, Peraturan Daerah (Perda) No 3 Tahun 2016 tentang Kesehatan Ibu, Bayi Baru Lahir, Bayi dan Anak Bawah Lima Tahun (KIBBLA) untuk mengurangi Angka Kematian Bayi (AKB) dan juga Angka Kematian Ibu (AKI) dalam proses implementasinya dilaksanakan oleh beberapa lembaga.

Adapun berdasarkan hasil wawancara dan observasi koridor atau lembaga pertama yang dilalui oleh kebijakan ini dalam implementasinya ialah Dinas Kesehatan Kabupaten Kupang yang berperan sebagai leading sector, karena merupakan koordinator bagi lembaga lainnya yang menjadi pelaksana kebijakan ini. Pada Dinas Kesehatan Kabupaten Kupang, Bidang Kesehatan Masyarakat (Kesmas) khususnya Seksi Kesehatan Keluarga dan Gizi yang bertanggung jawab melaksakan program-program dari Peraturan Daerah (Perda) No 3 Tahun 2016 tentang Kesehatan Ibu, Bayi Baru Lahir, Bayi dan Anak Bawah Lima Tahun (KIBBLA) untuk pengurangan kematian bayi.

Sebagai koordinator Dinas Kesehatan memiliki kepentingan dengan lembaga pelaksana lainnya untuk mendukung pelaksanaan Perda, oleh karena itu Dinas Kesehatan bertanggung jawab untuk membangun koordinasi dan komunikasi dengan lembaga-lembaga pelaksana lainnya, yaitu Pusat Kesehatan Masyarakat (Puskesmas) sebagai unit pelaksana 
teknis, aparat pemerintah kecamatan, kelurahan dan desa, serta organisasi atau lembaga swasta. Peran Dinas Kesehatan sebagai koordinator dalam membangun komunikasi antar lembaga dalam pelaksanaan kebijakan ini menjadi penting, hal ini seperti yang disampaikan oleh Talbot (2008:1571), bahwa koordinasi dan komunikasi menjadi suatu interaksi yang penting antara lembaga atau aktor pelaksana kebijakan untuk mendukung proses implementasi kebijakan Selain sebagai koordinator Dinas Kesehatan Kabupaten Kupang juga berperan sebagai pengawas lembaga-lembaga pelaksana lainnya dan melakukan evaluasi atas penyelenggaraan Peraturan Daerah (Perda) No. 3 Tahun 2016 tentang Kesehatan Ibu, Bayi Baru Lahir, Bayi dan Anak Bawah) Lima Tahun (KIBBLA).

Setelah melalui Dinas Kesehatan Kabupaten Kupang, proses implementasi Perda No. 3 Tahun 2016 tentang Kesehatan Ibu, Bayi Baru Lahir, Bayi dan Anak Bawah Lima Tahun (KIBBLA) selanjutnya dilaksanakan oleh 26 unit Puskesmas di Kabupaten Kupang. Puskesmas merupakan Unit Pelaksana Teknis (UPT) yang bertanggung jawab menyelenggarakan pembangunan kesehatan pada wilayah tingkat kecamatan. Bidang yang secara khusus bertanggung jawab atas pelaksanaan Perda ini ialah Bidang kesehatan ibu dan anak (KIA). Pada bidang KIA terdapat Bidang Koordinasi (Bikor) yang bertanggung jawab mengontrol pelayan kesehatan ibu dan anak, baik itu di Puskesmas maupun di Puskesmas Pembantu (Pustu) dan Pos Kesehatan Desa (Poskesdes) di tingkat desa.

Hadirnya Pustu dan Poskesdes merupakan upaya pemerintah untuk mendekatkan layanan kesehatan, khususnya layanan kesehatan ibu dan anak kepada masyarkat, khususnya bagi masyrakat desa yang sulit menjangkau pelayanan kesehatan. Ini juga merupakan salah satu cara yang dilakukan untuk mengurangi kematian bayi. Hal ini juga yang dilakukan oleh beberapa negara yang memiliki AKB yang tinggi, salah satunya ialah India, yang sejak tahun 2005 meluncurkan program yang sejenis yaitu National Rural Health Mission (NRHM) (Pandey \& Mohan, 2019:57).

Pelayanan kesehatan ibu dan anak pada Pustu dan Poskesdes di Kabupaten Kupang ditangani oleh Bidan, Bidan Desa (pada desa) dan perawat. Dalam pelaksanaanya bidan dan perawat di Pustu dan Poskesdes berkoordinasi dengan kader posyandu dan dukun bayi. Puskesmas juga berperan sebagai fasilitator bagi bidan desa dan kader serta kemitraan antara dukun bayi dan bidan dalam mendukung penyelenggaraan KIBBLA, selain itu peran lain dari Puskesmas adalah sebagai pendukung posyandu. Puskesmas sebagai unit pelaksana teknis memiliki kewajiban untuk melaporkan capaian program kepada Dinas Kesehatan. Tugas lainnya dari Puskesmas ialah mengkoordinir pelaksanaan Pelayanan KIBBLA pada jaringannya yaitu Pustu dan Poskesdes yang memberikan pelayanan pada cakupan wilayah yang lebih sempit yaitu pada desa dan kelurahan. Dalam pelaksanaan Perda No. 3 tahun 2016 tentang KIBBLA Puskesmas membangun komunikasi lintas sektor yang diwujudkan dalam bentuk mini dialog (minilog) yang dilakukan setiap triwulan sebagai sarana untuk mengkomunikasikan capaian pelaksanaan KIBBLA antara lintas sektor.

Lembaga lainnya yang melaksanakan Peraturan Daerah (Perda) No 3 Tahun 2016 tentang Kesehatan Ibu, Bayi Baru Lahir, Bayi dan Anak Bawah Lima Tahun (KIBBLA) untuk pengurangan kematian bayi di Kabupaten Kupang ialah RSUD Naibonat yang berperan untuk menerima rujukan dan merujuk pasien yang memerlukan tindakan medis lanjutan pada pasien-pasien yang tidak dapat ditangani oleh Puskesmas. Sesuai isi Peraturan Daerah (Perda) No 3 Tahun 2016 tentang Kesehatan Ibu, Bayi Baru Lahir, Bayi dan Anak Bawah Lima Tahun (KIBBLA) dikatakan bahwa rumah sakit umum bertugas sebagai tempat pelayanan medik, pelayanan instalasi, dan perawatan.

Selain lembaga-lembaga tersebut, Pemerintah Kecamatan, desa dan kelurahan juga memiliki peran dalam penyelenggaraan Peraturan Daerah (Perda) No 3 Tahun 2016 tentang 
Kesehatan Ibu, Bayi Baru Lahir, Bayi dan Anak Bawah Lima Tahun (KIBBLA) untuk pengurangan kematian bayi di Kabupaten Kupang. Adapun peran dari lembaga pemerintah Kecamatan, Lurah dan desa yaitu pertama sebagai Pendukung Penyelenggaraan KIBBLA, kedua sebagai penggerak dan pendorong masyarakat untuk mendukung pelaksanaan KIBBLA yaitu mendorong masyarakat khususunya ibu hamil untuk memeriksakan kandungan, dan melahirkan di fasilitas kesehatan serta menghimbau masyarakat agar segera memeriksakan anak yang sakit pada fasilitas kesehatan dan tenaga kesehatan. Ketiga, Desa dan kelurahan berperan untuk menyelenggarakan posyandu, dan Keempat, Desa memiliki peran juga sebagai pengontrol masyarakat dengan adanya Perdes Kesehatan ibu dan anak.

Masyarakat Kabupaten Kupang sebagai target penerima layanan juga memiliki peran penting untuk mendukung pelaksanaan Peraturan Daerah (Perda) No 3 Tahun 2016 tentang Kesehatan Ibu, Bayi Baru Lahir, Bayi dan Anak Bawah Lima Tahun (KIBBLA) untuk pengurangan kematian bayi. Pelibatan peran aktif masyarkat dalam implementasi kebijakan untuk pengurangan kematian bayi merupakan suatu yang penting. Khatri, Mishra, Khanal, Gelal, \& Neupane (2016:1) dari hasil penelitiannya mengatakan bahwa keputusan pemerintah untuk bekerja dalam kemitraan dengan masyarkat untuk memfasilitasi pelayanan yang tersedia dapat menjadi salah satu cara untuk memberikan pelayanan kesehatan untuk mengurangi kematian bayi. Adapun peran daripada masyarkat dalam implementasi Peraturan Daerah (Perda) No 3 Tahun 2016 tentang Kesehatan Ibu, Bayi Baru Lahir, Bayi dan Anak Bawah Lima Tahun (KIBBLA) peran dari suami dan keluarga untuk memperhatikan kesehatan ibu hamil, mengantarkan ibu hamil untuk memeriksakan kandungan, dan memastikan agar proses persalinan terjadi di fasilitas kesehatan (Faskes) yang memadai, mengantarkan anak yang sakit untuk mendapatkan pengobatan dan pertolongan dari tenaga kesehatan yang memadai.

Peran dari tokoh agama dan tokoh masyarakat adalah menghimbau masyarakat khususnya ibu hamil dan pihak keluarga untuk melakukan pemeriksaan kandungan, dan untuk mendorong agar ibu hamil melakukan persalinan di faskes dan ditolong oleh tenaga kesehatan. Kader posyandu dan dukun bayi berperan untuk membantu bidan dan perawat dalam pelayanan program kesehatan ibu hamil, ibu melahirkan, bayi dan balita, selain juga mengedukasi ibu untuk pemberian air susu ekslusif kepada bayi. Pemberian air susu esklusif merupakan suatu hal yang sangat penting dan dibutuhkan dalam upaya pengurangan kematian bayi, seperti yang ditunjukkan oleh hasil kajian dari Soraya, Purnaweni, \& Santoso (2014:1); Intifada \& Subowo (2017:3); Bhandari et al. (2019:8) bahwa pemberian asi eksklusif pada bayi selain untuk mengurangi resiko terkena penyakit dan kematian pada bayi juga bermanfaat dalam meningkatkan kualitas hidup ibu.

Apabila digambarkan konteks lembaga (institutional context) sebagai koridor atau struktur prosedur operasi atau lembaga-lembaga pelaksana dari Peraturan Daerah (Perda) No 3 Tahun 2016 tentang Kesehatan Ibu, Bayi Baru Lahir, Bayi dan Anak Bawah Lima Tahun (KIBBLA) untuk pengurangan kematian bayi di Kabupaten Kupang adalah seperti gambar 3 berikut: 


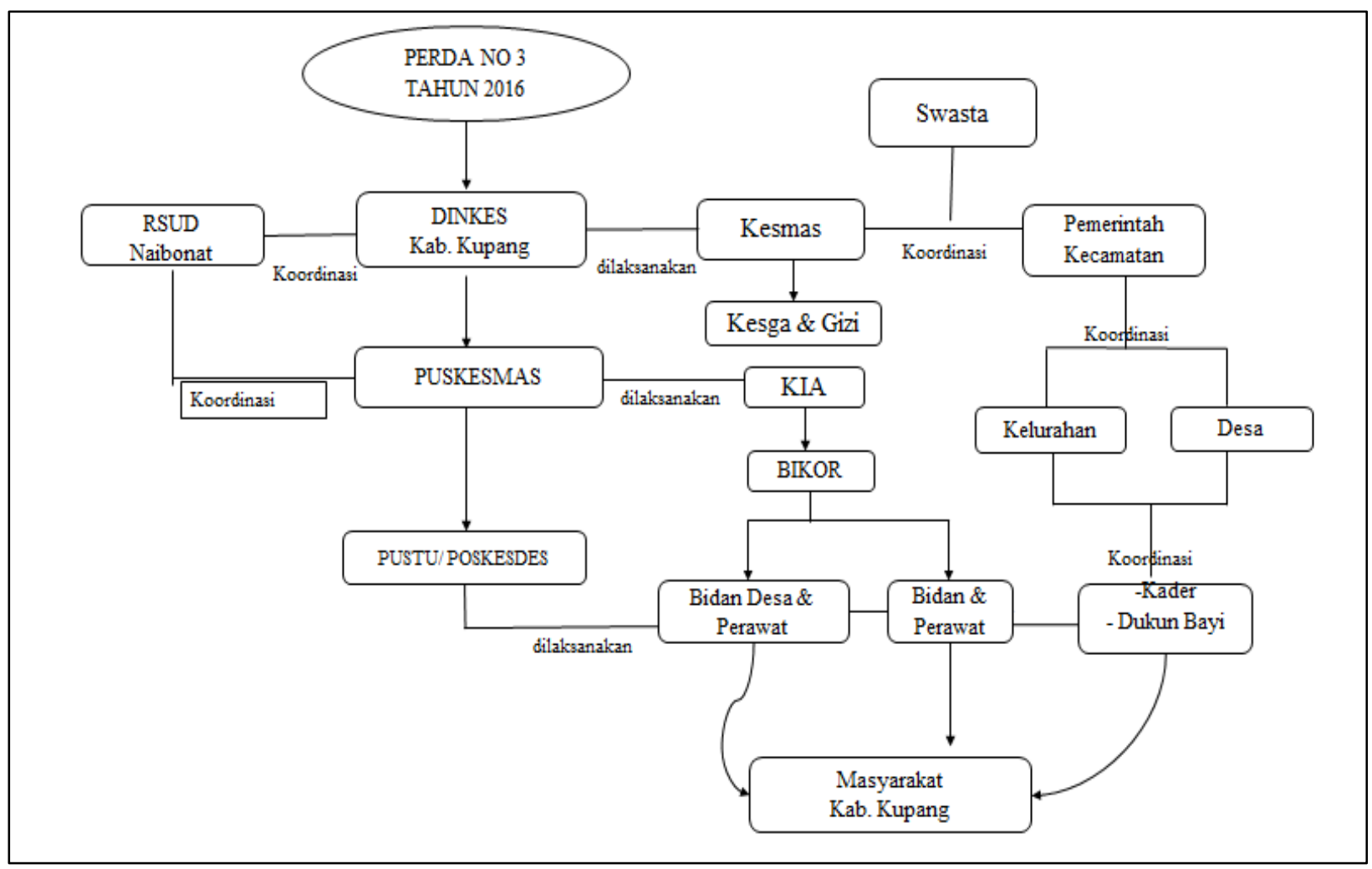

Gambar 3.

Lembaga- Lembaga Pelaksana Peraturan Daerah (Perda) No 3 Tahun 2016 tentang Kesehatan Ibu, Bayi Baru Lahir, Bayi dan Anak Bawah Lima Tahun (KIBBL) (Sumber: Olahan Hasil Penelitian, 2019)

\section{Aktor Kunci Pelaksana Perda No 3 tahun 2016}

Aktor kunci dalam Implementasi Peraturan Daerah (Perda) No 3 Tahun 2016 tentang Kesehatan Ibu, Bayi Baru Lahir, Bayi dan Anak Bawah Lima Tahun (KIBBLA), merujuk pada identifikasi aktor yang paling berpengaruh atau mempengaruhi proses implementasi kebijakan. Berkenaan dengan aktor yang paling berpengaruh dalam implementasi Perda No 3 tahun 2016 dari hasil penelitian diketahui bahwa aktor kunci dalam implementasi Perda No. 3 tahun 2016 untuk pengurangan kematian bayi di Kabupaten Kupang ialah (1) bidankhususnya bidan desa, (2) perawat dan (3) kader posyandu. Pertimbangannya, karena bidan desa dan kader posyandu memegang peranan penting dalam implementasi kebijakan kesehatan ibu dan anak khususnya implementasi Perda yang bertujuan mendekatkan layanan kesehatan kepada masyarakat. Gambar 3 menunjukkan para aktor yang berhadapan dengan masyarakat. Hal ini menunjukkan bahwa aktor kunci merupakan sumber informasi, dan agen perubahan yang memfasilitasi pengadaptasian kebijakan masyarakat lokal. Apalagi dengan kondisi desa-desa di Kabupaten Kupang yang masih sulit akses transportasinya sehingga masih sulit bagi masyarakat untuk pergi ke Puskesmas, maka hadirnya bidan desa dan kader posyandu di masyarakat menjadi sesuatu yang sangat dibutuhkan.

Apabila melihat pada konsep street-level bureaucrat oleh Lipsky (1980); Tummers \& Bekkers (2014:3) maka Perawat dan Bidan desa sebagai aktor kunci dalam proses implementasi Peraturan Daerah (Perda) No 3 Tahun 2016 tentang Kesehatan Ibu, Bayi Baru Lahir, Bayi dan Anak Bawah Lima Tahun (KIBBLA) untuk pengurangan kematian bayi dapat dikatakan sebagai street-level bureaucrat. Hasil kajian Mthethwa (2012:38) menunjukkan aktor kunci yang berada di lapangan memainkan peran yang penting dalam 
implementasi kebijakan karena mereka dituntut untuk dapat membuat keputusan saat lansung berhadapan dengan masyarakat.

Dalam hal ini bidan desa sebagai pelaksana lapangan merupakan aktor yang paling banyak berhubungan langsung dengan masyarakat desa, sehingga terlaksana dengan baik atau tidaknya program dan juga bagaimana penerimaan masyarakat Kabupaten Kupang, khususnya yang berada di desa terhadap kebijakan kesehatan ibu dan anak juga sangat tergantung dari sikap bidan desa dalam memberikan pelayanan kesehatan. Wimmelmann, Vallgårda, \& Jensen (2018) dari hasil kajiannya juga menyampaikan bahwa profesionalitas dari pelaksana tenaga kesehatan lapangan yang terbentuk dari komitmen, pengetahuan dan pengalaman memegang peranan penting dalam implementasi kebijakan kesehatan.

\section{Hubungan Kepentingan dan Kekuasaan antara lembaga pelaksana Peraturan Daerah (Perda) No 3 Tahun 2016 tentang Kesehatan Ibu, Bayi Baru Lahir, Bayi dan Anak Bawah Lima Tahun (KIBBLA)}

Konteks lembaga (institutional context) dalam implementasi Perda No. 3 Tahun 2016 tentang Kesehatan Ibu, Bayi Baru Lahir, Bayi dan Anak Bawah Lima Tahun (KIBBLA), selanjutnya yang diidentifikasi ialah hubungan kepentingan dan kekuasaan antara dan di dalam lembaga yang terkait. Hasil penelitian seperti pada Gambar 3 menunjukkan bahwa lembaga- lembaga dan juga aktor pelaksana memiliki perannya masing-masing yang saling membutuhkan dalam proses pelaksanaan kebijakan. Hal ini juga seperti yang disampaikan oleh Purwanto \& Sulistyastuti (2015:153) bahwa jenis implementasi yang menggunakan struktur multi organisasi memiliki konsekuensi bahwa koordinasi antar unit organisasi dan aspek kerjasama antara aktor pelaksana menjadi sangat penting. Oleh karena itu dari segi kepentingan, setiap lembaga memiliki kepentingan untuk bekoordinasi dan berkomunikasi dengan lembaga lain. Dalam implementasi Peraturan daerah No 3 tahun 2016 tentang Kesehatan Ibu, Bayi Baru Lahir, Bayi dan Anak Bawah Lima Tahun (KIBBLA), terjadi hubungan komunikasi dan koordinasi antara lembaga pelaksana. Berkenaan dengan hubungan komunikasi antara lembagamenunjukkan program KIBBLA Puskesmas membangun komunikasi dan koordinasi dengan lembaga pelaksana lainnya.

Koordinasi antara aktor pelaksana juga dapat dikatakan sebagai variabel yang signifikan berkontribusi pada implementasi kebijakan kesehatan dasar (Ali, 2018:317). Oleh karena itu apabila di dalam proses implementasi kebijakan ada lembaga yang mengalami masalah pada koordinasi dan komunikasi di dalam internal lembaga, juga akan berdampak pada pelaksanaan kebijakan oleh lembaga lain. Hal inilah yang terjadi pada proses implementasi Peraturan Daerah (Perda) No 3 Tahun 2016 tentang Kesehatan Ibu, Bayi Baru Lahir, Bayi dan Anak Bawah Lima Tahun (KIBBLA), dimana antara Pemerintah Kecamatan dengan Pemerintah tingkat Kelurahan dan Desa memang memiliki koordinasi dan komunikasi, tetapi Pemerintah Kecamatan tidak memberikan instruksi atau perintah yang sifatnya memaksa Lurah dan Kepala Desa dalam implementasi program KIBBLA sehingga di lapangan terlihat kurangnya partisipasi aktif dan komitmen yang kuat dari Lurah dan Kepala Desa dalam mengimplementasikan Perda No 3 tahun 2016 tentang Kesehatan Ibu, Bayi Baru Lahir, Bayi dan Anak Bawah Lima Tahun (KIBBLA), untuk pengurangan kematian bayi, padahal selain hubungan koordinasi dan komunikasi antara lembaga pelaksana, hubungan formal dan informal antara lembaga pelaksana memegang peranan penting dalam implementasi kebijakan (Mendes \& Aguiar, 2017:1106).

Lurah dan Kepala Desa juga tidak mempunyai kewenangan memaksa warga untuk mengikuti program yang berkaitan dengan pelaksanaan Perda pengurangan kematian bayi, 
ini dikarenakan Lurah dan Kepala Desa hanya memberikan himbauan kepada warga. Hal inilah yang ternyata membuat proses implementasi Peraturan Daerah (Perda) No 3 Tahun 2016 tentang Kesehatan Ibu, Bayi Baru Lahir, Bayi dan Anak Bawah Lima Tahun (KIBBLA) belum mencapai tujuan yang diharapkan, karena tidak semua lembaga pelaksana berpartisipasi aktif melakukan apa yang seharusnya dilakukan untuk mendukung proses implementasi. Kurangnya dukungan dan kesadaran lembaga pelaksana dalam melaksanakan kebijakan sebagai faktor yang menghambat proses implementasi kebijakan juga tunjukkan oleh kajian yang dilakukan oleh Khan \& Khandaker (2016:541); Oktaviani, Suryoputro, dan Sriatmi (2018:17); Febriandini, Rengga, dan Marom (2016:8).

Kurangnya partisipasi aktif dari lembaga pelaksana Peraturan Daerah (Perda) No 3 Tahun 2016 tentang Kesehatan Ibu, Bayi Baru Lahir, Bayi dan Anak Bawah Lima Tahun (KIBBLA) telihat di daerah penelitian yaitu Kecamatan Kupang Tengah dan Kecamatan Kupang Timur, dimana belum ada desa dan kelurahan yang membuat sosialisasi khusus untuk menginformasikan isi dan tujuan dari program KIBBLA kepada masyarakat khususnya berkenaan dengan peran masyarakat dalam penyelenggaraan program KIBBLA. Informasi dari beberapa warga di lokasi penelitian menunjukkan bahwa mereka mendapatkan info tentang program KIBBLA yang berkaitan dengan larangan untuk penggunaan dukun bayi, kewajiban untuk melahirkan di Fasilitas Kesehatan hanya melalui obrolan dengan kader posyandu dan pada saat kegiatan Posyandu. Oleh karena itu secara konteks lembaga (institutional context) belum mendukung atau bahkan dapat dikatakan sebagai salah satu variabel yang menghambat implementasi kebijakan kesehatan ibu dan anak di Kabupaten Kupang. Kurangnya peran aktif dan komitmen dari lembaga pemerintah tingkat Kelurahan dan tingkat Desa di Kabupaten Kupang dalam mendukung implementasi Perda No 3 Tahun 2016 terjadi karena pihak kelurahan dan Desa di Kabupaten Kupang juga menjadi pelaksana dari berbagai program dan kebijakan lainnya seperti kebijakan "Taman Eden" sebagai program unggulan pemerintah Kabupaten Kupang untuk pemberdayaan ekonomi warga, kebijakan pengembangan desa wisata, dan kebijakan pembangunan infrastruktur desa.

Hal ini seperti yang dikatakan oleh Najam (1995:43) bahwa banyak lembaga yang berbeda akan secara langsung atau tidak langsung terlibat dalam pelaksanaan kebijakan dan program tertentu, tetapi juga lembaga-lembaga tertentu akan terlibat langsung atau tidak langsung dalam pelaksanaan banyak kebijakan dan berbagai program yang berbeda-beda. Karena lembaga-lembaga ini terlibat sebagai pelaksana dari berbagai program lainnya, maka akan membentuk perbedaan komitmen dalam melaksanakan suatu jenis kebijakan. Hal ini pula yang menjadi tantangan dalam context implementasi kebijkan publik yang dilaksanakan oleh banyak lembaga yaitu berupa perbedaan-perbedaan yang dimiliki oleh setiap lembaga (Czunyi, 2012:46). Dalam hubungannya dengan komitmen pelaksana, prioritas lembaga tersebut akan membentuk respons lembaga terhadap kebijakan. Hal ini pula yang terjadi pada implementasi Peraturan Daerah (Perda) No 3 Tahun 2016 tentang Kesehatan Ibu, Bayi Baru Lahir, Bayi dan Anak Bawah Lima Tahun (KIBBLA) dimana pada saat ini prioritas utama dari pemerintah Desa di Kabupaten Kupang ialah pada pembangunan infrastruktur dan juga pembuatan Perdes untuk infrastruktur dan Pariwisata, sehingga berdampak pada rendahnya komitmen mereka dalam melaksanakan Perda No. 3 tahun 2016 untuk pengurangan kematian bayi.

\section{Karateristik Lembaga Pelaksana Perda No 3 Tahun 2016}

Upaya pemahaman akan konteks lembaga dalam implementasi Peraturan Daerah (Perda) No 3 Tahun 2016 tentang Kesehatan Ibu, Bayi Baru Lahir, Bayi dan Anak Bawah Lima Tahun (KIBBLA) selanjutnya dilakukan dengan menganalisis karateristik lembaga 
yang secara struktur dipengaruhi oleh kondisi sosial, ekonomi, politik dan aturan hukum dimana mereka beroperasi. Namun dalam penelitian ini karateristik lembaga pelaksana Perda No. 3 Tahun 2016 hanya dilihat dari kondisi sosial dan ekonomi. Secara sosial lembaga pelaksana Perda No. 3 Tahun 2016 ialah lembaga pemerintah. Dinas Kesehatan Kabupaten Kupang sebagai organisasi pemerintah daerah Kabupaten Kupang yang bertanggung jawab pada seluruh kesehatan masyarakat Kabupaten Kupang, RSUD Naibonat juga turut bertanggung jawab ubtuk memberikan pelayanan kesehatan ibu dan anak, Kemudian Puskesmas sebagai pelaksana teknis yang harus bertanggung jawab atas pelaksanaan program kepada Dinas Kesehatan.

Secara ekonomi Dinas Kesehatan, RSUD Naibonat dan Puskesmas dalam pelaksanaan Peraturan Daerah (Perda) No 3 Tahun 2016 tentang Kesehatan Ibu, Bayi Baru Lahir, Bayi dan Anak Bawah Lima Tahun (KIBBLA) mendapatkan sumber keuangan dari Anggaran Pendapatan Belanja Daerah (APBD) Kabupaten Kupang, sehingga kedua institusi tersebut juga secara langsung mendapat pengawasan dari pemerintah daerah Kabupaten Kupang. Lebih jauh lagi, karena merupakan institusi pemerintah maka semua staf dari Dinas Kesehatan dan Puskesmas harus turut mendukung dan berupaya untuk mencapai tujuan dari Perda No. 3 tahun 2016 sesuai dengan tupoksinya.

Pemerintah Kecamatan merupakan pihak yang bertanggung jawab untuk berkoordinasi dan membangun komunikasi dengan pihak kelurahan dan Desa untuk pelaksanaan kebijakan. Namun yang terjadi di lapangan, tidak semua kelurahan dan desa di Kabupaten Kupang melakukan apa yang seharusnya dilakukan untuk mendukung pelaksanaan kebijakan, padahal seharusnya terjadi koordinasi dan komunikasi antara kelurahan dan desa dengan pihak kecamatan. Dari segi ekonomi Kecamatan dan Kelurahan menggunakan anggaran dari Anggaran Pendapatan dan Belanja Daerah (APBD) sementara desa dalam penyelenggaraan program KIBBLA menggunakan anggaran yang berasal dari anggaran Dana Desa.

\section{Realitas Lingkungan Kabupaten Kupang dalam Implementasi Perda No 3 tahun 2016}

Upaya pemahaman konteks (context) dalam implementasi juga dilakukan dengan menganalisis realitas lingkungan dimana kebijakan tersebut diimplementasikan. Hal ini sesuai dengan apa yang dikatakan oleh Warwick (1984) bahwa secara konteks perbedaan umum antara program yang berjalan dan yang gagal yaitu terletak pada: Pertama, hubungan antara tujuan kebijakan dengan realitas lingkungandan yang kedua disebabkan oleh lingkungan yang invariant dan irrelevan (Najam, 1995:42). Merujuk pada konsep ini maka Peraturan Daerah (Perda) No 3 Tahun 2016 tentang Kesehatan Ibu, Bayi Baru Lahir, Bayi dan Anak Bawah Lima Tahun (KIBBLA) dalam proses implementasinya juga dihadapkan pada permasalahan realitas lingkungan Kabupaten Kupang yang dilihat secara geografis dan sosial.

Realitas lingkungan di Kabupaten Kupang yang petama yaitu dari segi geografi berupa luasnya wilayah dan iklim yang kurang kondusif. Permasalahan lingkungan dalam implementasi kebijakan kesehatan juga seperti yang dikemukakan oleh hasil kajian dari Joshi (2015:2); Belton, Myers, \& Ngana (2014:2); Poerwanto, Stevenson, \& Klerk (2003:493) bahwa pelaksanaan program kesehatan publik dihadapkan pada berbagai atribut lingkungan yang membuat kompleks permasalahannya. Kabupaten Kupang memiliki luas wilayah $4.937 .62 \mathrm{~km}^{2}$ dengan iklim yang umumnya beriklim tropis dan kering dimana musim hujan sangat pendek yaitu 3-4 bulan, sedangkan musim kemarau 8-9 bulan sehingga alamnya cenderung kering. 
Permasalahan lingkungan lainnya ialah jarak antara desa dan fasilitas kesehatan berupa Puskesmas yang sulit dijangkau oleh masyarakat, karena puskesmas hanya bisa dijangkau masyarakat desa tertentu, namun sulit bagi warga desa-desa lain yang dalam kasu ini, dilihat dari lokasi penelitian di Kecamatan Kupang Tengah dan Kupang Timur hanya beberapa desa yang memiliki jarak dekat dengan Puskesmas, seperti untuk wilayah Kecamatan Kupang Timur yang memiliki 8 Desa dan 5 Kelurahan, hanya satu desa dan dua kelurahan yang secara jarak cukup dekat untuk mengakses puskesmas. Sementara untuk wilayah Kecamatan Kupang Tengah yang terdiri atas 7 desa dan 1 kelurahan, terdapat 3 desa yang memiliki jarak yang cukup jauh untuk mengakses Puskesmas. Selain itu, jarak antara rumah penduduk yang umumnya berjauhan dan terbatasnya akses jalan dan transportasi ke desa-desa yang menyulitkan bagi para petugas kesehatan dalam menjalankan tugasnya juga menjadi faktor penghalang dalam implementasi kebijakan pengurangan bayi.

Realitas lingkungan lainnya dalam implementasi Peraturan Daerah (Perda) No 3 Tahun 2016 tentang Kesehatan Ibu, Bayi Baru Lahir, Bayi dan Anak Bawah Lima Tahun (KIBBLA) untuk pengurangan kematian bayi datang dari sosial masyrakat yaitu berupa minimnya pendidikan. Data BPS Kabupaten Kupang (2018) menunjukkan bahwa 30,31\% masyarakat Kabupaten Kupang rata-rata memiliki pendidikan hanya setingkat pendidikan tingkat Sekolah Dasar (SD). Rendahnya tingkat pendidikan masyarkat setempat khususnya ibu dapat menjadi salah satu faktor yang menyebabkan implementasi kebijakan pengurangan kematian bayi gagal mencapai tujuan (Yustiawa \& Nandini (2018:126); Patterson \& Bose (2017:1). Selain karena minimnya pendidikan, minimnya informasi tentang kesehatan ibu dan anak yang diterima oleh masyarakat membuat kesadaran masyarakat akan pentingya kesehatan ibu dan anak juga masih minim. Ini seperti yang telah dijelaskan di atas yaitu kurangnya peran serta aktif dari pihak Desa dan Kelurahan untuk menginformasikan kepada masyarakat dan juga terbatasnya sosialisasi yang dilakukan oleh pihak Dinas Kesehatan tentang program KIBBLA.

Realitas lingkungan sosial budaya lainnya yang menjadi catatan dalam implementasi kebijakan kesehatan ibu dan anak di Kabupaten Kupang ialah adanya tradisi budaya Se'i. Masyarakat Timor memiliki tradisi lokal untuk mengasapi ibu dan anak selama 40 hari pertama kelahiran bayi di dalam ume $k u b u^{l}$. Tujuan Se'i ini adalah mempercepat pemulihan kesehatan ibu setelah melahirkan dan menguatkan daya tahan tubuh bayi, yang justru memberikan dampak buruk bagi kesehatan ibu dan bayi karena dari proses pemanggangan berpengaruh buruk pada pernafasan. Penelitian tradisi lokal ini pernah dilakukan, yaitu tentang perilaku pribadi dan faktor sosial budaya seperti Tradisi Se'i berdampak negatif pada kesehatan bayi, yang tentu mempengaruhi angka kematian bayi secara umum di wilayah yang mempraktekkan kebiasaan tersebut (Soerachman, 2014:56).

\section{E. PENUTUP}

Implementasi Peraturan Daerah (Perda) No 3 Tahun 2016 tentang Kesehatan Ibu, Bayi Baru Lahir, Bayi dan Anak Bawah Lima Tahun (KIBBLA) sebagai kebijakan untuk pengurangan kematian bayi di Kabupaten Kupang dalam implementasinya secara konteks lembaga (institutional context) dilaksanakan oleh beberapa lembaga, yaitu: Dinas Kesehatan Kabupaten Kupang sebagai leading sektor, Puskesmas, Pustu dan Posdes di wilayah Kabupaten Kupang sebagai pelaksana teknis dari Dinas Kesehatan, RSUD Naibonat, Pemerintah Kecamatan, Kelurahan, dan Pemerintah Desa sebagai pendukung dan penggerak

\footnotetext{
${ }^{1}$ Rumah adat lopo masyarakat Timor
} 
masyarakat, kader posyandu yang berkoordinasi dengan bidan dan bidan desa, dan masyarakat Kabupaten Kupang sebagai pendukung kebijakan. Aktor kunci dalam implementasi kebijakan ini ialah bidan, perawat, bidan desa dan juga kader posyandu, mereka adalah pihak yang paling mempengaruhi implementasi kebijakan kesehatan ibu dan anak, karena merekalah yang lansung berhadapan dengan masyarakat dalam memberikan pelayanan kesehatan ibu dan anak, khususnya bidan desa dan kader posyandu yang berperan untuk menjangkau dan mendekatkan layanan kesehatan kepada masyarakat di wilayah desa.

Secara hubungan kepentingan diketahui setiap lembaga pelaksana kebijakan dalam proses implementasi membutuhkan dukungan dari lembaga pelaksana lainnya. Dalam implementasi Peraturan Daerah (Perda) No 3 Tahun 2016 tentang Kesehatan Ibu, Bayi Baru Lahir, Bayi dan Anak Bawah Lima Tahun (KIBBLA) diketahui tidak semua lembaga pelaksana melakukan perannya secara aktif dalam mendukung pelaksanaan kebijakan, yaitu pada lembaga pelaksana pemerintah Kelurahan dan pemerintah Desa dan juga masyarakat Kabupaten Kupang, hal ini mungkin berkaitan dengan tidak adanya suatu perintah atau instruksi dari Pemerintah tingkat Kecamatan untuk memaksa Pemerintah tingkat kelurahan dan desa, dan juga tidak adanya kewenangan Pemerintah Desa untuk memaksa masyarakat untuk melaksanakan Perda No 3 tahun 2016, kecuali apabila desa membuat Peraturan Desa yang lebih mengikat dan memaksa masyarakat. Adanya Lembaga Pemerintah Kelurahan dan Desa dan juga masyarakat Kabupaten Kupang yang tidak aktif melakukan perannya inilah yang menjadi masalah dalam implementasi kebijakan ini, sehingga implementasi kebijakan tidak dapat mencapai tujuannya, yaitu untuk mengurangi kematian bayi di Kabupaten Kupang.

Implementasi Peraturan Daerah (Perda) No 3 Tahun 2016 tentang Kesehatan Ibu, Bayi Baru Lahir, Bayi dan Anak Bawah Lima Tahun (KIBBLA) untuk pengurangan kematian bayi di kabupaten Kupang dihadapkan pada realitas lingkungan Kabupaten Kupang yang kurang mendukung, yaitu dari segi geografi berupa luasnya wilayah dan iklim dengan curah hujan yang rendah, dari segi masyarkatnya yang sebagian besar memiliki tingkat pendidikan hanya sekolah dasar, dan juga dari faktor budaya masyarakat berupa tradisi masyarakat Kabupaten Kupang untuk melakukan Se'i atau pemanggangan dan pengasapan kepada ibu dan bayi setelah persalinan. Berbagai kondisi ini justru menjadi penghambat dalam implementasi kebijakan.

Rekomendasi untuk mengurangi kematian bayi di Kabupaten Kupang. Pertama Pemerintah Kabupaten Kupang perlu memberikan perhatian kepada aktor kunci dalam implementasi kebijakan ini, yaitu bidan desa dan kader. Kedua, Pemerintah kecamatan perlu mengeluarkan kebijakan Peraturan Camat tentang pengurangan angka kematian bayi kepada Desa atau Kelurahan, termasuk berkaitan dengan tradisi lokal Se'i. Selajutnya, Peraturan Camat ini kemudian menjadi Peraturan Desa (Perdes) yang kemudian menjadi panduan bagi aparatur desa dan seluruh pemangku kepentingan di desa.

\section{DAFTAR PUSTAKA}

Akinlo, A. E., \& Sulola, A. O. (2019). Health care expenditure and infant mortality in subSaharan Africa. Journal of Policy Modeling, 41(1), 168-178. https://doi.org/10.1016/j.jpolmod.2018.09.001

Ali, M. M. (2018). Primary Health Care Policy Implementation Performance in Bangladesh : Affecting Factors. Journal of Public Administration and Governance, Vol. 8, (March). https://doi.org/10.5296/jpag.v8i1.12782

ASEAN Community Relation Division. (2017). Maternal And Child Mortality In Indonesia. 
https://asean.org

Badan Pusat Statistik Kabupaten kupang. (2019). Kabupaten Kupang dalam Angka. https://kupangkab.bps.go.id

BAPPENAS. (2016). Laporan Perkembangan Pencapaian Tujuan Pembangunan Milenium Indonesia. Jakarta: Bappenas.go.id

Bayrakal, S. (2006). The U.S. Pollution Prevention Act: A policy implementation analysis. Social Science Journal, 43(1), 127-145. https://doi.org/10.1016/j.soscij.2005.12.012

Belton, S., Myers, B., \& Ngana, F. R. (2014). Maternal Deaths In Eastern Indonesia: 20 Years and Still Walking: An Ethnographic Study. BMC Pregnancy and Childbirth, 39 (14) 1-10 http://www.biomedcentral.com/1471-2393/14/39

Bhandari;, S., Thorne-Lyman; A. L., Shrestha; B., Neupane;, S., Nonyane;, B. A. S., \& West, K. P. (2019). Determinants of infant breastfeeding practices in Nepal: a national study. International Breastfeeding Journal, 14 , 1-17 https://doi.org/10.118613006-019$\underline{028}$

Chaya, W., Jesdapipat, S., Tripetchkul, S., Santitaweeroek, Y., \& Gheewala, S. H. (2019). Challenges and Pitfalls In Implementing Thailand's Ethanol Plan: Integrated Policy Coherence and Gap Analysis. Energy Policy, 132 (June), 1050-1063. https://doi.org/10.1016/j.enpol.2019.06.061

Creswell, J. W., \& Creswell, J. D. (2018). Research Design: Qualitative, Quantitative \& Mixed Methods Approaches. Los Angeles : SAGE Publication

Czunyi, S. (2012). Enhancing Institutional Effectiveness for Climate Change Adaption. Thesis. Departement of enviromental science and policy of central european university. https://www.idrc.ca/en/resources/perspectives/climate-change communications -andcollaboration

Dinas Kesehatan Kabupaten Kupang. (2019). Laporan Tahunan Program Kesehatan Ibu dan Anak Kabupaten Kupang.

Dongol, Y. (2011). A Policy Gap Analysis of Convention on International Trade in Endangered Species of Wild Fauna and Flora (CITES) Implementation in Nepal. https://doi.org/10.25148/etd.FI11050901

Dye, T. R. (1976). What Government Do, Why They Do it, What Difference it Makes. Tuscaloosa, Ala: Alabama Press.

Edward, G. C. (1980). Implementing Public policy. Washington D.C: Congressional Quarterly Inc.

Febriandini, A. P., Rengga, A., \& Marom, A. (2016). Studi Implementasi Program Kesehatan Ibu dan Anak di Puskesmas Tlogosari Kulon Kota Semarang. Journal of Public Policy and Management Review, 5 (2) 603-607. DOI 10.14710/jppmr.v5i2.

Grindle, M. (1980). Politics And Policy Implementation In The Third World. New Jersey: Princeton University Press.

Intifada;, S., \& Subowo, A. (2017). Implementasi Peraturan Walikota Semarang Nomor 7 Tahun 2013 tentang Peningkatan Pemberian ASI Eksklusif (Studi di Puskesmas Pegandan Kecamatan Gajahmungkur Kota Semarang). Journal of Public Policy And Management Review, 6 (2). 322-325. DOI 10.14710/JPPMR.V6I2.15998

Joshi, M. (2015). Comprehensive Peace Agreement Implementation and Reduction In Neonatal, Infant and Under-5 Mortality Rates In. BMC International Health and Human Rights, 15 (27). 1-10. https://doi.org/10.1186/s12914-015-0066-7

Khan, A. R., \& Khandaker, S. (2016). A Critical Insight into Policy Implementation and Implementation Performance. Public Policy and Administration, 15 (4). 538-548. DOI.10.13165/VPA-16-15-4-02 
Khatri, R. B., Mishra, S. R., Khanal, V., Gelal, K., \& Neupane, S. (2016). Newborn Health Interventions and Challenges for Implementation in Nepal. Front Public Health, 4(15). 1-7. DOI: $10.3389 /$ fpubh.2016.00015

Kismartini, \& Bungin, B. (2019). Wilayah Pesisir Indonesia: Narasi Kebijakan Publik Masalah Pesisir dan Pulau-Pulau Kecil di Indonesia. Jakarta: Prenada Media Group.

Lipsky, M. (1980). Street-level bureaucrac. New York: Russell Sage Foundation.

Martin, E. (2014). Implementing an International Health Treaty in Small Pacific Island Nations. Thesis. School of Medicine Faculty of Health Deakin University. http://hdl.handle.net/10536/DRO/DU:30066234

Mendes, V. L. P. S., \& Aguiar, F. C. (2017). Implementation of public health policy and its challenges in the digital age. Brazilian Journal of Public Administration, 51(6). 11041121. DOI: http://dx.doi.org/10.1590/0034-7612169426

Miles, M. B., \& Huberman, A. M. (1994). Qualitative Data Analysis. (second; R. Holand, Ed.). Thousand Oaks: SAGE Publication.

Mthethwa, Richard Mduduzi. (2017). Evaluating the Implementation of the Child Support Grant in South Africa: the case of Kwazulu-Natal Province. Thesis. Faculty of Economic and managent Sciences school of Public management and Administration university Pretoria. http://pdfs.semanticscholar.org

Najam, A. (1995). Learning From The Literature On Policy Implementation: A Synthesis Prespective. Laxenbug: IIASA.

Nugroho, R. (2014). Public Policy (5th ed.). Jakarta: PT Elex Media Komputindo.

Nurani, F., Mardiyono, Supriyono, B., \& Wijaya, A. F. (2018). Analysis of Policy Implementation to Decline Mother and Infant Mortality Rate Through The Five C's Protocol (Study Of East Java Province). International Journal of Social and Local Economic Governance (IJLEG), 4 (1), 26-31. http://ijleg.ub.ac.id

Oktaviani, F. A., Suryoputro, A., \& Sriatm, A. (2018). Analisis Implementasi Kebijakan Peraturan Daerah Nomor 2 Tahun 2015 Tentang Keselamatan Ibu dan Anak di Kota Semarang. Jurnal Kesehatan Masyarakat, 6 (1). 17-26. http://ejournal3.undip.ac.id

Pandey, A., \& Mohan, A. (2019). The role of national rural health mission in reducing infant mortality rate in India. International Journal of Health Governance, 24(1), 56-65. https://doi.org/10.1108/IJHG-09-2018-0044

Parsons, W. (2014). Public Policy: Pengantar Teori Dan Praktik Analisis Kebijakan (5th ed.). Jakarta: Kencana Prenadamedia Group.

Patterson, J., \& Bose, C. (2017). Education to Reduce Neonatal Mortality in Low Resource Environments. Pediatrics, 139 (5). 1-2. DOI: https://doi.org/10.1542/peds.2016-4172

Paudel, N. R. (2009). A Critical Account of Policy Implementation Theories: Status and Reconsideration. Journal of Public Policy and Governance, 25 (2). 36-54. http://pdfs.semanticscholar.org

Peterson, A. S. (2003). Public Policy: Enscyclopedia of Public Adminisstration and Public Policy (J. Rabin, Ed.). New York: Marcel Dekker, Inc.

Poerwanto, S., Stevenson, M., \& Klerk, N. de. (2003). Infant mortality and family welfare: policy implications for Indonesia. J Epidemiol Community Health, 57 (7). 493-498. http://dx.doi.org/10.1136/jech.57.7.493

Pressman, J. L., \& Wildavsky, A. (1984). Implementation: How Great Expectations in Washington Are Dashed in Oakland; Or, Why It's Amazing that Federal Programs Work at All, This Being a Saga of the Economic Development Administration as Told by Two Sympathetic Observers Who Seek to Build Morals . university of California press. 
Purwanto, E. A., \& Sulistyastuti, D. R. (2015). Implementasi kebijakan Publik: konsep dan Aplikasinya Di Indonesia. Yogyakarta: Gava Media.

Soerachma, R. (2014). Kesehatan Ibu Dan Bayi yang Melakukan Tradisi Sei dan Gambaran Kesehatan Lingkungan Rumah Bulat (Ume 'Kbubu) di Kabupaten Timor Tengah Selatan Provinsi Nusa Tenggara Timur (NTT). Jurnal Kesehatan Reproduksi, 5 (1) 59-66. http://ejournal.litbang.depkes.go.id

Soraya, Ike., Purnaweni, Hartuti., Santoso, R. Slamet. (2014). Implementasi Program Pemberian Air Susu Ibu (ASI) Eksklusif di Kota Salatiga. Journal of Public Policy and Management Review, 3(2). 347-357. DOI 10.147/jppmr.v3i2.5165

Suwitri, S. (2008). Konsep Dasar Kebijakan Publik. Semarang: Universitas Diponegoro.

Swartz, M. K. (2013). Infant Mortality Revisited. Journal of Pediatric Health Care, 27 (6). 407. https://doi.org/10.1016/j.pedhc.2013.09.003

Talbot, C. (2008). International Journal of Public Performance Regimes - The Institutional Context of Performance Policies. International Journal of Public Administration, 31(14). 1569-1591. DOI:10.1080/01900690802199437

Tummers, L., \& Bekkers, V. (2014). Policy implementation, street-level bureaucracy and the importance of discretio. Public Management Review, 16 (4). 527-547. https://doi.org/10.1080/14719037.2013.841978

UNICEF. (2018). Progress for Every Child in The SDG Era. New York. UNICEF Data and Analytics Section Division of Data, Research and Policy. https://data.unicef.org

United Nations. (2019). The Millennium Development Goals Report 2015. New York.

Warwick; D. P. (1982). Bitter Pills : Population Policies and Their Implementation in Eight Developing Countries. Cambridge: Cambridge University Pers.

Wimmelmann, C. L., Vallgårda, S., \& Jensen, A. M. (2018). Meet the local policy workers: Implementation of health promotion guidelines in Denmark. Public Policy and Administration, Vol. 33(1). 66-87. DOI: 10.1177/0952076716683568

Winarno, B. (2012). Kebijakan Publik: Teori, Proses Dan Studi Kasus (2nd ed.). Yogyakarta: CAPS.

Yeremias.T, K. (2014). Enam Dimensi Strategis Administrasi Publik: Konsep, Teori dan Isu (3rd ed.). Yogyakarta: Gava Media.

Yustiawa, T., \& Nandini, N. (2018). Literasi Informasi Kesehatan Nifas Ibu Hamil Berstatus Sosial Menengah ke Bawah. Jurnal Administrasi Kesehatan Indonesia, 6 (2). 122-128. http://dx.doi.org/10.20473/jaki.v6i2.2018.122-128 
